\title{
Morality Politics and Prostitution Policy in Brussels: A Diachronic Comparison
}

\author{
Magaly Rodríguez García \& Kristien Gillis ${ }^{1}$
}

Published in Sexuality Research and Social Policy, Sept 2017:

https://link.springer.com/article/10.1007/s13178-017-0298-5

\section{Abstract}

This paper discusses the genealogy of prostitution policies in Brussels through the lens of morality politics. It uses the analytical framework proposed by Hendrik Wagenaar and Sietske Altink (2012) to compare the formulation and implementation of policies in the nineteenth and early twentieth centuries with today's policymaking in Brussels as well as the discourses underlying those policies. Although it departs from the six characteristics of morality politics, the study introduces one element that adds to the complexity of policymaking in this domain: gender. We argue that a gendered ideology and stigma have informed past and present prostitution policies in Brussels and that the many actors involved in the city's policymaking have more often than not relied on emotions and personal views on female sexuality to support their calls for the control or outright repression of public commercial sex. The comparative analysis illustrates the persistent symbolic nature of policy formulation and a blatant disregard for data, both of which have led to the approval of unworkable laws and sudden policy shifts. However, the participation of new actors in the debates

\footnotetext{
${ }^{1}$ M. Rodríguez García, History Department, Research Unit Modernity and Society, 1800-2000, KU Leuven, Blijde-Inkomststraat 21 - 3000 Leuven, Belgium. Email: magaly.rodriguez@kuleuven.be K. Gillis, Political Science Department, Stadscampus, Sint-Jacobstraat 2-4, 2000 Antwerp, Belgium. Email: kristien.gillis@uantwerpen.be
} 
about prostitution in recent years has ushered in an increase in questionings of morality politics and will hopefully bolster calls for fact-based policies.

Keywords: Prostitution; Morality Politics; Brussels; History of prostitution; Prostitution policies; Regulation; Abolition; Sex workers' movement.

\section{Introduction $^{2}$}

This paper provides a comparative analysis of the policies on prostitution that have been enacted in Brussels from the nineteenth century to the present. In line with Wagenaar and Altink (2012), who define prostitution policy as "an instance of morality politics" (p. 279), we focus on the local to identify the commonalities and differences in discourses and prostitution policies that have emerged over time. Hence this study departs from the morality framework proposed by Wagenaar and Altink by utilizing a historical perspective. This temporal comparison serves two purposes: it facilitates a better understanding of today's policies by drawing attention to similarities with the past (Howell et al., 2008), and it highlights the entrenched stigma surrounding the issue and the increasing diversification of the actors involved in the debates on prostitution and policymaking that have been ongoing since the nineteenth century. Furthermore, by undertaking a theoretical and historical discussion of commercial sex, the paper stresses the ideological underpinnings of policies on

\footnotetext{
${ }^{2}$ We would like to express our gratitude to the journal's three anonymous reviewers for their helpful detailed comments and to Mark Wyers for his meticulous editing of our work. Also, many thanks to Maarten Loopmans and Pieter Vanhees for their critical readings of this paper and inspiring discussions on the subject, as well as for providing us with useful materials. We are also grateful to María Alejandra Molina for helping us with the design of the maps of Brussels.
} 
prostitution and adds an important dimension to its characterization as morality politics: gender.

A gendered conception of commercial sex as deviant behavior has prevailed in the prostitution policies enacted in most societies. Prostitution is primarily seen as a female activity, while procuring, pimping and the buying of sexual services are most often linked to men. A historical overview of the notions that have been used in different times and societies to refer to the sex trade shows that although some terms could apply to men and women, the most common nouns for prostitute only allude to women (Rodríguez García, 2016). Despite the fact that some regions in the world have had a rich tradition of male and trans prostitution, most legal contexts have defined prostitution as a female undertaking, and in some contemporary societies that is still the case. In Turkey, for instance, the law prescribes that all sex workers employed in licensed brothels need to be female by birth or by gender reassignment surgery. In present-day Bolivia and Mexico, trans sex workers are not allowed to work in brothels and are usually confined to street prostitution (van Nederveen Meerkerk, 2017).

In this paper, we take Brussels as a case study to emphasize the gendered and moralistic logic that has dominated the city's prostitution policies since the nineteenth century. We argue that in spite of the various national legal frameworks that have been put into place, including the regulation of prostitution between 1844 and 1948 and its subsequent abolition, the authorities have continuously sought to monitor socalled deviant female sexual behavior. The study systematically compares the policymaking that was implemented in Brussels in the nineteenth and early twentieth centuries to today's discourses, including the formulation and implementation of new prostitution policies. We have two reasons for focusing on policymaking and law 
enforcement on public sex work: first, public opinion and political responses to prostitution are mostly informed by overt manifestations of sex work; and second, there is more information about public commercial sex, as sources about (the impact of policies on) private or hidden forms of prostitution in the past are scarce.

We use Wagenaar and Altink's framework to analyze the role played by morality in local policymaking. In their view,

Morality politics indicates a situation where the minimum common ground, that is a condition for engaging in effective collective problem solving, has broken down into irreconcilable conflict over moral positions about what is right or virtuous with regard to the issue at hand. (Wagenaar \& Altink, 2012, p. 282)

Six intertwined characteristics set morality politics apart from other fields of policy. Morality politics is ruled by ideology and because it can be appropriated by anyone, it is emotionally charged and resistant to empirically-based facts; for that reason, it focuses on policy formulation and discourses rather than implementation and is prone to drastic shifts (Wagenaar \& Altink, 2012). These characteristics, along with gender, shape the three sections of this paper. In the first part, we discuss the definition of morality politics and elaborate on the issues of ideology and gender by means of a theory of prostitution and historical insights. The second section provides a diachronic analysis of prostitution policies in Brussels to illustrate the part played by moralistic gendered discourses in the constant revision of laws. In the third section, we present an overview of the main state and non-state actors involved in the debates and formulation of those policies, and we stress the emotions and lay knowledge that have 
informed policymaking in Brussels over time. That issue is analyzed separately because we believe that the shifts in and diversification of (visible and less visible) actors that have occurred in the last two centuries represent the most prominent change and perhaps provide a means of transforming the morality politics surrounding prostitution into evidence-driven policy. We conclude with a critical analysis of past and present prostitution policies in Brussels and propose some corrective measures that can benefit both sex workers and the local population that shares the urban spaces of the city with them.

\section{Morality Politics and Prostitution}

Although values are at the core of all public policy, in morality politics they take the form of dogma and reduce the complexity of a social phenomenon to a fixed normative framework. The set of principles that comprises the basis of morality politics is often presented as being incontrovertibly true and representative of "a vehicle for a larger moral cause" (Wagenaar \& Altink, 2012, p. 283), which explains its pedagogical nature. With regards to prostitution, past and present supporters of repression seem to be the most prone to proselytizing. Like the contemporary marketing of the Swedish model which seeks to eliminate demand (Levy \& Jakobsson, 2014) and the promotion of the French goal "to change mentalities" by criminalizing clients (Mathieu, 2015), the abolitionist, social purity and antitrafficking (or so-called "white slavery") campaigns of the nineteenth and early twentieth centuries sought on a global scale to spread the idea that prostitution is an evil. The sophisticated methodology used by the League of Nations in the 1920s to "prove" the existence of "a traffic of considerable dimensions" (League of Nations, 
1927, p. 43) conflated prostitution with organized crime. The campaigns that were launched gave force and symbolic value to all of the private institutions and state actors that sought to repress trafficking and commercial sex (Chaumont, 2009; Rodríguez García, 2012).

The idea that prostitution is a problem is widespread, even among advocates of regulation. Throughout time and space, the terms used to describe prostitution have nearly always involved a condemnation of "atypical" sex acts. In spite of the geographical and temporal differences in how the sex trade has been practiced and policed, the existing literature demonstrates that sexual desire has been deemed socially disruptive in most cultures. As it became increasingly commodified with the rise of industrial societies, the nation-state and globalization, commercial sex was transformed into an issue that preoccupied elites and the bourgeoisie (Foucault, 1976). In particular, women who engaged in sex for purposes other than procreation were (and in many places still are) incriminated to varying degrees (Peršak \& Vermeulen, 2014).

Female promiscuity has been condemned in all patriarchal societies because it makes it difficult for men to determine paternity and, from women's point of view, it makes it hard to secure healthy, faithful husbands or partners. The nexus between female licentiousness and financial or material gain exacerbates men's anxiety in terms of their traditional roles as family heads and breadwinners. In short, the "female capacity of opportunistic promiscuity threatens the very premise of the patriarchal family, and the prostitute is a constant reminder of this ability" (Edlund \& Korn, 2002, p. 208). Furthermore, in contrast to policies surrounding other forms of (female) work, those enacted with regard to prostitution are heavily influenced by emotions and personal views about female sexuality and intimacy. Some people see 
sex work as being indicative of human's ability to adapt to harsh circumstances or they understand it in terms of emancipation, but many others see prostitution as the quintessential symbol of female oppression (Rodríguez García, van Nederveen Meerkerk, \& Heerma van Voss, 2017).

Such theoretical insights can help us better understand the other aspects that characterize most prostitution policies as morality politics. Since the debates and policies surrounding prostitution are often reduced to normative arguments that are presented as absolute and self-evident truths (Crowhurst, 2017), everyone feels entitled to propose measures to solve "the problem". As Crowhurst (2017) and Weitzer (2010) argue, this has led to a proliferation of discourses and laws based on unsubstantiated claims or "facts" that depict the sex industry as being intrinsically exploitative and harmful. In turn, that explains the dramatic stories about (young) females being dragged into prostitution that tend to dominate media reports and the findings of abolitionist advocacy groups and public institutions.

The roots of that tendency run deep. In the second half of the nineteenth century, women involved in prostitution were increasingly seen as victims. By the late Victorian era, feminists and libertarians helped publicize a series of sexual scandals, including news reports about Jack the Ripper and the murder of five prostitutes in London in 1888. William Stead's newspaper report (1885) about the abduction of English girls who were then allegedly sold into Continental brothels and the media's focus on the Ripper murders rendered all men suspect and strengthened the notions of urban danger and female fragility (Walkowitz, 1982).

As a result of such forms of gendered logic, discourses and policy formulation took precedence over the implementation of regulations and their effects. All this often led to unworkable laws or naive recommendations. By the end of the 1930s, Dr. 
J.A. Cavaillon, who was secretary general of the Union Internationale contre le Péril Vénérien (International Union for Combating Venereal Diseases) and technical inspector of the French Ministry of Health, drew attention to the purchasing side of prostitution - a Swedish model avant la lettre. He called for the criminalization of (male) third parties, the elimination of brothels and the suppression of pornography as a means to encourage "normal sexual life" among women and men. Encouraging early marriage and providing counter-attractions for men (such as cultural centers, public libraries, cinemas, game fields and swimming pools) were seen as useful ways to reduce male demand for commercial sex (Cavaillon, 1939).

Like the criminalization of clients today, Cavaillon's approach emphasized in the name of protecting women and gender equality - men's active participation in the sex industry and relegated women to a secondary role. Even today the popularity of such a harm-based analysis of prostitution is on the rise (Harrington, 2017). In 2014, the European Parliament approved a nonbinding resolution which recommends that EU countries re-evaluate their policies with the aim of reducing demand for prostitution and trafficking by punishing clients. France, which was a regulationist country par excellence until 1946, has now become a champion of abolitionism. In April 2016, the French government passed a law that bans buying sex and requires that convicted clients attend classes highlighting the dangers associated with prostitution (Lavaud-Legendre, 2017). In Belgium, while the spokesman for the Ministry of Justice declared that there are currently no plans to push for the criminalization of clients (Beel, 2016, 8 April), increased repression and attempts to enact legislation which would lead to fines on buyers of sex and street prostitutes in Brussels' Alhambra quarter has alarmed social organizations and sex workers' representatives (BRUZZ, 2016, 28 June). 
As the next sections of this paper argue, prostitution policies in Brussels display all the characteristics of morality politics as identified by Wagenaar and Altink (2012). Moreover, gender and the idea(1) of "proper" female sexual behavior have had a strong influence on policymaking and they led to drastic changes starting in the nineteenth century. In this way, discourses and policies regarding prostitution have responded to the moral climate and local interests rather than the rights and living conditions of sex workers themselves.

\section{Gendered ideology and changing rules}

Brussels, which was officially named the Brussels-Capital Region in 1989, consists of nineteen municipalities, which have enjoyed a great deal of autonomy since the creation of the Belgian state in the 1830s. The Municipal Law of 1836 delegated the preservation of social order, including the control of prostitution, to the local authorities, but not all of the municipalities have had policies relating to commercial sex. In the early twentieth century, nine municipalities had clear sets of rules, but today only three of them do: the City of Brussels (most often just referred to as "Brussels"), Sint-Joost-ten-Node and Schaarbeek (Brussels Hoofdstedelijk Gewest, 2015; Majerus, 2017).

A gendered ideology has underpinned the region's policies on prostitution. A system of regulation was introduced in Brussels in 1844 and used as a model for other Belgian cities. The lobby behind regulation, which was mainly voiced by military doctors and hygienists, was heavily influenced by the ideas of the French theorist Alexandre Parent-Duchâtelet, who described prostitutes as being as inevitable as sewers (de Schaepdrijver, 1986; Parent-Duchâtelet, 1838). The city's authorities 
argued that a system of regulation would help deal with that "shameful plague" (Bulletin communal, 1857, p. 201). The increasing popularity of the idea of prostitution as a necessary evil was followed by the conviction that it needed to be isolated from "respectable" people and strictly controlled as a means of containing the physical and moral dangers that it purportedly entailed. A virtually carceral system of regulation consisting of legal brothels, hospitals, prisons and reformatories was created as a way to achieve those goals.

Belgian abolitionists who wanted to do away with the regulation system also treated commercial sex as an abject activity that needed to be uprooted from society. Jurists writing for the Pandectes belges - a Belgian law encyclopedia published between 1878 and 1948 - defined prostitution as abandonment to immorality, lust, bawdiness, debauchery and prurience (Picard et al, 1886). Isidore Maus (1929), chairman of the Comité National Belge de Défense contre la Traite des Femmes et des Enfants (Belgian National Committee of Defense against the Traffic of Women and Children), described it more succinctly as "profit-driven lechery" (p. 1). Backed by a press scandal about white slavery in Brussels, they managed to spread their abolitionist cause in both official and popular circles in the last decades of the nineteenth century (Chaumont, 2011).

Municipal regulations on prostitution were abolished in 1948 but the logic of prostitution as an inevitable nuisance prevails. Belgian law prohibits public soliciting, advertising, procuring and the operation of brothels but not prostitution itself. As was the case in the past, prostitution is currently tolerated but not socially accepted. Since the turn of the century, the municipalities of Brussels have tended to maintain a mixed policy of a laissez-faire approach to private (luxury, online) sold sex and male or trans sex work and the de facto regulation of street and window prostitution (Brussels 
Hoofdstedelijk Gewest, 2015). All of the laws are inscribed in a policing framework that is meant to secure social order, especially in areas undergoing processes of gentrification. Even though street prostitution exists in various parts of the Brussels region, police regulations and law enforcement tend to focus on the Alhambra quarter, which is situated in the City of Brussels (see Map 1). The current regulations enforced in Schaarbeek and Sint-Joost resemble those of the nineteenth century in that they attempt to confine window prostitution to a few streets and ostensibly protect local residents from the real or imaginary adverse effects that are usually associated with sexually-oriented activities (such as violence, diseases, drugs, traffic, and so on) (David \& Loopmans, 2017; Weitzer, 2014).

Other characteristics of morality politics as identified by Wagenaar and Altink (2012) can be seen in Brussels' past and present policies, such as the primacy of policy formulation over policy implementation as well as a tendency to make drastic changes and ad hoc decisions (Loopmans, 2013). Contemporaries characterized the set of rules introduced in Brussels in 1844 as "hyper-regulationism" because it was even stricter than the French model. It was expected that such an ideal form of "hygienic prostitution" would make it possible to carefully control the women working in authorized brothels (filles de maison, or "brothel girls") and those operating in so-called maisons de passe (filles éparses, or "dispersed girls"), as well as delimit the urban spaces in which brothels could operate, offer a means of supervising brothel keepers, limit the number of maisons de passe and minimalize clandestine and street prostitution. However, the rigidity of the system and the arbitrary power and corruption of the municipal police - along with changing mentalities concerning (sexual) entertainment - failed to produce results and led to a swift change of strategy. In 1877, the Brussels authorities approved an amendment to 
the 1844 law, the aim of which was to persuade filles éparses and clandestine prostitutes to register. The law also stressed a desire to hide commercial sex from the public eye, which involved a dwindling of the medical argument and a strengthening of the moral one. That change required that the power of the police be increased through the creation of a vice squad, which in turn led to the further marginalization of the women involved in prostitution (Huberty \& Keunings, 1987).

Public criticism of the regulation system, however, was widespread. The white slavery scandal of the late 1800 s, the re-introduction of strict laws on prostitution during and immediately after the First World War, and the impetus generated by the abolitionist agenda of the League of Nations strengthened the Belgian anti-regulation lobby (Rodríguez García, 2012). A proposal was made to suspend the existing laws for a period of six months, and it was approved by forty-one of the forty-two councilors of the City of Brussels in 1924. The experiment, which also entailed the suspension of the abhorred compulsory health controls, led to an influx of sex workers from other municipalities and loud protests by local residents. The authorities then decided to bring back regulation in 1925, and that system was in force until the Belgian Parliament approved its abolition in 1948 (Majerus, 2017). An abolitionist legal framework remained in effect until the 1980s in the form of what Maarten Loopmans and Pieter Van Den Broeck (2011) have called “unregulated tolerance” (p. 6). With that system, the local authorities intervened only occasionally to quell social disorder and to relocate (formally illegal) commercial sex venues or street prostitutes to other parts of the urban landscape. Since the last decades of the twentieth century, debates about prostitution, the spread of sexually transmitted diseases, increased migration and international crime have come to the fore yet again and resulted in harsher local discourses and policies intended to control commercial sex. 
The authorities in Brussels have recently adopted the language of human trafficking and passed laws purportedly aimed at protecting all victims of sexual exploitation. In practice, the laws make no clear differentiation between voluntary and forced prostitution and they tend to focus on female sex workers and urban development. As Marion David and Maarten Loopmans (2017) argue, the laws remain "dependent upon the whims of municipal authorities. Indeed, prostitution (in particular its visible form) is under constant threat of relocation by various attempts to purify, gentrify and renew inner cities” (p. 86). Yvan Mayeur (from the Socialist Party), who was mayor of the City of Brussels until June 2017, was actively involved in forbidding street prostitution in the zone around the Alhambra quarter. Ideas about how to achieve that goal have shifted from attempts to control prostitution through zoning and timing laws (street prostitution only being allowed in certain areas at certain times) to limiting the influx of clients (by placing roadblocks and implementing systems of fines), as well as by discouraging the establishment of sex work venues (through extra taxes, intensified control of prostitution hotels and bars, investing in buildings and determining the nature of commercial activities in neighborhoods) and relocating sex workers to Albert II Avenue (BRUZZ, 2016, 9 September). Since June of 2016, sex workers in the Alhambra quarter have been forced to deal with overtly repressive measures such as increased policing and the issuance of fines, as well as more symbolic acts such as the removal of the benches where they would take breaks (BRUZZ, 2014, 10 September). The newly appointed municipal authorities, too, are taking an uncompromising stance. Philippe Close (from the Socialist Party), the new mayor of Brussels, declared in a recent interview that prostitutes and clients of prostitution in the Alhambra quarter will no longer be tolerated (DH.be, 2017, 21 August). 
Window prostitution is under attack as well. Emir Kir (from the Socialist Party), who is the incumbent mayor of Sint-Joost-ten-Node, has openly stated that he is in favor of a policy of zero tolerance for illegal activities that "exploit women's sexuality". Increased police activity, higher certification fees for bars and other places where (female) prostitution is carried out, and mandatory closing hours were all seen as a means to achieve that aim. After sex workers' representatives stridently protested those steps and the owners of commercial sex establishments and social workers took the case to the Council of State (the supreme administrative court in Belgium), the Sint-Joost authorities were forced to back down (BRUZZ, 2016, 22 February \& 30 May). The situation in Schaarbeek is also rather paradoxical. While the municipal laws were supposed to eliminate window prostitution, a system in which permits are issued to sex workers and brothel managers has been introduced. Such moves are, in fact, quite reminiscent of earlier forms of regulation. According to an official source, the idea behind the "pragmatic policy" in Schaarbeek is to use a strict system of control as a way to achieve abolition in the long run (Brussels Hoofdstedelijk Gewest, 2015).

Amid this proliferation of policies, some positive changes have occurred. The increased participation of prostitutes and social workers in today's debates as well as increased scholarly attention to the (self-)perceptions and experiences of the people involved in commercial sex have the potential to introduce a bottom-up approach to prostitution policies. To a certain extent, the voices of sex workers are now being heard by the Brussels authorities. For instance, sex worker representative Sonia Verstappen was asked to take part in a workshop on prostitution organized in October of 2015 by the Brussels Observatory for Prevention and Security. But while all of the other speakers, including researchers, city officials and social workers, were given 
twenty minutes each to voice their views, Verstappen was only given ten minutes.

Moreover, the nametag she was given only included her first name; visibly annoyed, she took a pen out of her purse and wrote her last name on it. That anecdote illustrates the depersonalization that has characterized the prostitution policies that have been implemented to this day. Indeed, as the following section demonstrates, the journey to treating sex workers as meaningful actors in their own right has been long and arduous.

\section{Actors and lay knowledge}

In what follows, we compare state and non-state actors' past and present contributions to prostitution policymaking in Brussels. We look at the specific problem construction as well as the interactions between the actors involved, the types of expertise they have relied on and the impact of their involvement. By doing so, we would like to see if we can speak of "usual suspects" (such as public authorities and doctors) over the course of time and whether the passing of centuries has brought about game changers in local policymaking.

Since the nineteenth century, municipal authorities have played a key role in debates about prostitution and the drafting of related policies in Belgium. Despite the existence of a national legal framework for regulating prostitution that was in place until 1948, municipal autonomy has led to a variety of strategies and levels of tolerance and repression at the local level. The common themes in local regulations in the nineteenth century involved concerns about social disorder, moral decline and physical degeneration. By the late 1800 s, a notable new actor influencing the debates on prostitution had arisen: the abolitionist lobby, which contested the idea of 
prostitution as an inevitable evil and put forward a moral code that would end the regulation of such a "vile activity" (Maus, 1929, p. 2).

Today, the local authorities in Brussels do not explicitly describe prostitution as an evil but insist on depicting it as "a problem" obstructing the development of residential and business areas so that they can be safe and orderly. For that reason, the problems associated with prostitution but not the problems within prostitution itself are at the heart of local policy debates and the formulation of laws. However, the current identification of problems in Brussels is primarily limited to female prostitution and particular red-light zones such as Schaarbeek and Sint-Joost-TenNode (window prostitution), as well as the Alhambra quarter (street prostitution) in the capital (see Map 2). Other forms of commercial sex, such as male and trans prostitution in parks, and prostitution in places such as Albert II Avenue, the (gay) bars in the city center, the South Station area, and (along and around) Louisa Avenue are not as much the subject of repressive controls, if at all. Unless major problems occur there, such areas of prostitution are not strictly policed. This can probably be explained by the absence of bars, nightclubs and hotels related to commercial sex on the broad avenues where street sex workers are picked up by car, the predominance of (young) residents tolerant of urban nightlife in more central areas and a disregard for sex work in parks and non-residential areas (e.g. Av. Albert II) that escapes the public eye.

Since the nineteenth century, city officials have sought the active participation of local police in the implementation of laws regarding prostitution. Over time the police started to internalize hegemonic discourses on prostitution but nowadays they seem to problematize local policies more than prostitution itself. This issue is connected to the two tasks that the police are charged with carrying out: applying 
local regulations and monitoring prostitution in light of criminal investigations. At times that has led to corruption and caused friction between the various divisions of the police and the police and other authorities. Just as in the past, prostitution policies tend to detract from trust-building efforts with sex workers that would facilitate infiltration into (potential) criminal networks. As a result of increased migration and an intensified focus on human trafficking following the fall of the Iron Curtain, the police are expected to repress prostitution and treat sex workers as both (potential) victims and informers. In a field interview, Karine Minnen, who is the head of the Brussels vice brigade, stated that the police often "get contradictory orders". She went on to explain: "We receive instructions from the juridical police and an officer from the administrative police. While one of them says 'everybody has to go', ${ }^{3}$ the other tells me to avoid penalizing prostitutes because they are victims, saying that we need to make sure they don't slip into clandestine prostitution" (Gillis, formal interview with the head of the vice police, January, 2016). Minnen argues that she and her colleagues are opposed to the fining and relocation of prostitutes because such exclusionary measures can put them into more dangerous and precarious situations, and she stated that she is disheartened by the fact that the municipal authorities do not take such issues into account. Such a situation reflects the primacy of policy formulation over policy implementation and leads to a different kind of problem construction.

Non-governmental actors have also seen prostitution in different ways in the course of the last few centuries. The current input of non-state actors, ranging from health professionals, abolitionists, the media, residents, social workers, scholars and

\footnotetext{
${ }^{3}$ This is a reference to the measures targeting displacement which the City of Brussels has been trying to push through in recent years.
} 
sex workers themselves, indicates that some interesting changes have occurred but also reveals numerous commonalities with the past. Hygienists, doctors and abolitionists active at the local level had their heyday in the 1800 s and the first half of the twentieth century. While the authority of health professionals was uncontested and seen as key to the development of the regulation system of the nineteenth century, it is currently neglected by city officials. Today, doctors, psychologists and nurses active in Brussels tend to be more aligned with the social organizations that provide assistance to those working in prostitution.

Social workers are not new actors in the Brussels scene, but their stance regarding prostitution has undergone an important shift. The more sympathetic stance of today's social workers is most probably the result of the bolstering of secularization and professionalization that occurred in the twentieth century. Whereas the notion of prostitution as "deviant behavior" informed early social work and the ideas of hospital staff (often nuns) involved in "social re-adaptation" programs, new forms of knowledge have likely altered the mentality of personnel working with prostitutes. There are signs that this had already occurred by the middle of the twentieth century but more research is needed to establish the timing and nature of such a shift in mentality. Primary sources point to the role played by the authorities, abolitionist activists and sex workers in that process. Developments in psychiatry and evidence of sex workers avoiding the mandatory health checks motivated the authorities to experiment with new methods of treating the presumed mental and physical problems of women involved in prostitution. In 1924, when the City of Brussels briefly experimented with the abolition of regulation, municipal authorities opened an anti-venereal dispensary where treatment was voluntary, free of charge, confidential and available to both men and women. 
That move heralded the introduction of more efficient and less draconian measures. In the 1930s, Brussels abolitionist Isidore Maus supported the League of Nations' campaign to link the treatment of venereal diseases to rehabilitation programs involving professional social workers, residential accommodation, training for employment and after-care (League of Nations, 1936). These ideas seem to have contributed to the acknowledgment of the socio-economic and cultural complexity of prostitution (Massin, 2014). Social organizations in Brussels today such as Espace P, Entre 2 and Alias focus on the wellbeing of their clients and take into account the stigmatization and lack of rights of those working in prostitution. Furthermore, the psychosocial work of Alias challenges gendered views of prostitution by focusing on male sex workers.

Contemporary social organizations' bottom-up approach to sex work stands in contrast to the moralist and gendered points of view of abolitionists. As in the past, abolitionists today tend to focus on female prostitution and incorporate it into a broader agenda that is opposed to patriarchy and male sexual domination. As with the municipal authorities, they concentrate on the phenomenon and disregard the personal motivations and needs of sex workers. Over time, however, abolitionists have started to move away from the local level and focus instead on lobbying at the national and international levels. They no longer participate in local debates but nonetheless remain influential as their discourses on human trafficking and prostitution are often used by city officials to justify stringent measures. Their sensationalist and emotionbased accounts of prostitution also influence local residents.

The complaints of people living in or around red-light areas in Brussels have not changed much since the nineteenth century (Majerus, 2017). Like in the past, their disapproval of prostitution stems from both practical and moralist grievances. 
Complaints about the sometimes real but sometimes exaggerated problems and threats (in relation to health, gender norms, crime and urban deterioration) caused by sex workers, third parties and/or clients have remained constant, and they go hand in hand with repeated calls to the city authorities to create family-oriented and businessfriendly urban spaces. Such people describe prostitution as a hindrance to city development and often appeal to subjectivities such as, "How can I explain this to my six-year old daughter?" (BRUZZ, 2016, 21 April). ${ }^{4}$ But while past complaints were made by the bourgeois residents of the Sablon area in the upper town, current antiprostitution activism focuses on the Alhambra quarter (See Map 2).

Commercial sex existed in the Alhambra quarter in the nineteenth century (Huberty \& Keunings, 1987) but the area's recent gentrification has brought with it an assertive and well-educated middle-class that uses all of the means available to them to protest prostitution. The "Alhambra committee", which was founded in 2012, has repeatedly called on the local authorities to take a firm stance against prostitution. The committee's members use traditional and new social media to vent their views and find supporters for their actions. In February 2015, for example, some of them installed an "anti-seat system" in their buildings to prevent sex workers from sitting on windowsills while waiting for clients (De Standaard, 2016, 16 February).

The media has always played an important role in the dissemination of popular discourses on prostitution and, indirectly, in how the authorities have responded to it. At the end of the nineteenth century, foreign (especially British) newspapers provoked a media scandal on the issue of white slavery in Brussels which led to the strengthening of the abolitionist movement in Belgium and abroad (Chaumont, 2011). Sensationalist stories dominated reporting on prostitution in

\footnotetext{
${ }^{4}$ Resident's online comment to Kristien Gillis' opinion piece in the local newspaper BRUZZ.
} 
Brussels until well into the twentieth century. Nowadays, national and local media outlets vary greatly in how much exposure they give to the various people involved in the debates on prostitution and policymaking. Local media outlet $B R U Z Z$ holds to a fairly neutral position and gives voice to both sides of the debate, including local policymakers and residents on the one hand and social organizations, sex workers' representatives and scholars on the other.

Indeed, the local debate has become polarized between those who stress concerns about moral issues and urban development, and those who use the language of rights to propose policies that guarantee the wellbeing of everyone living and working in areas where prostitution is carried out. The three relatively new nongovernmental actors involved in the prostitution debate are sex workers, human rights activists and scholars. Until recently, sex worker activism in Brussels was not as visible as it was in other European cities (Hubbard, 2004). A deliberation group created in 2013 that was tasked with coming up with alternative police regulations only involved the police and social organizations, and sex workers were represented by Espace P and Entre 2. In the summer of 2014, street sex workers active in the Alhambra quarter wrote an open letter to the mayor of Brussels explaining the negative effects of the new police regulations on their working conditions (BRUZZ, 2014, 16 July).

In November 2015, a few sex workers created the Union des travailleur(se)s du sexe organize(e)s pour l'independence (UTSOPI, Union of Sex Workers Organized for Independence), which has become a member of the International Committee on the Rights of Sex Workers in Europe (ICRSE). UTSOPI denounces the "whore hunts" that have been carried out in Brussels and other Belgian cities, and it has done so in close collaboration with Alias, Espace P and the Human Rights League 
(ICRSE, 2016, 3 August). While the latter has remained rather silent, sex workers' representatives are becoming increasingly vocal and visible in local debates about prostitution. Although UTSOPI's goal of de-stigmatizing prostitution in the near future seems utopian, the public appearances of its spokespersons, Sonia Verstappen and Maxime Maes, give a human face to sex work and may open the door to more dialogue with city officials and residents. In particular, Verstappen's background as a social scientist and former sex worker may be of great value in bridge-building between all of the actors involved (DeRedactie.be, 2011, 2 March). Like Alias, UTSOPI stresses the need to go beyond gendered views of prostitution and includes male and trans sex workers in its ranks. Whether the organization becomes truly inclusive (i.e. integrating all forms of prostitution and non-European sex workers) remains to be seen, but a strong movement that includes all aspects of sex work, as well as more systematic research, would benefit advocates of evidence-driven policies.

Little scholarly research on prostitution in Brussels has been done but it is clear that young academics are becoming increasingly involved in the debates and they are working harder to gather empirical data. We realize that there are limits to the knowledge that can be gathered about prostitution and stress the need to include sex workers in academic and political debates so that we can create more comprehensive analyses and less morally-charged policies. In fact, an attempt to do just that was made a decade ago. In 2007, ministers Évelyne Huytebroeck (from the Green Party) and Pascal Smet (from the Socialist Party) commissioned Belgian and Dutch researchers to trace the contours of a fact-based prostitution policy for the whole region of Brussels. Their final report included a quantitative and a qualitative study of policies on prostitution and the organization of the trade in Brussels, a 
comparison with three European cities (Antwerp, Glasgow and Rotterdam), and an exploratory design for an integral prostitution policy (van den Hazel et al., 2008). The initiative failed when Smet presented the initial findings of the project to the parliament of Brussels and came under attack by abolitionist members of the francophone Christian-democratic party. Again that was the result of the stigma attached to commercial sex and the predominance of lay knowledge that informs prostitution policies.

A critical assessment of the "expertise" that opponents to prostitution in Brussels have relied on since the nineteenth century leads us to conclude that the data used in such debates is highly biased and skewed. Then and now, the policies implemented in Brussels have been drafted by self-declared experts who exploit public fears and inflate numbers to push their agenda. In the nineteenth century, the “pseudo-scientific program” (Majerus, 2003, p. 8) drawn up by military doctors, public hygienists and other social engineers stressed not only the threat that "moral degeneration" posed to society but also the health and security risks of uncontrolled commercial sex. In a positivist environment that strove to measure and categorize every aspect of social life, advocates of regulation used statistical material to "prove" that there was a need to maintain strict control of the women involved in prostitution and publicize the alleged success of the system. Detractors used the same official statistics to demonstrate the failure of the system of regulation by focusing on the percentage of registered prostitutes infected with syphilis. That situation led to what Aurore François and Christine Machiels (2007) eloquently refer to as "a war of numbers".

However, abolitionists chose to ignore figures that did not support their cause, including the increasing number of infected clandestine prostitutes (even though those 
statistics were also biased), information about prostitutes' social backgrounds and migratory patterns (as that would humanize them), and the declining number of regulated brothels. Ironically, the continuation of the system of regulation bolstered abolitionists' media campaign against white slavery. The emotions invoked by images of innocent young women forced into legal brothels and fears of social decay are not so different from the shocked reactions of contemporary abolitionists and those residents of Brussels who automatically link commercial sex to human trafficking and/or other crimes in their neighborhoods. According to Jan Leerman, spokesman of the Alhambra committee, the quarter is "infested" with prostitutes, pimps and Mafiosi (Dauvillé, 2015, 21 March). The study commissioned by ministers Huytebroeck and Smet indicates that there were between 105 and 135 streetwalkers active in four different areas of the Brussels region; a minority of them worked in the Alhambra quarter and because of various kinds of pressure their numbers started to decrease in 2003 (van den Hazel et al., 2008).

Since the nineteenth century, public authorities and laypersons have misused official data or produced their own "facts" to justify their strong stance on prostitution. Today's city officials seem to value the anecdotal information provided by residents more than the scientific results put forward by scholars. Sex workers, social assistants and other activists have had some impact on local regulations by taking cases to court, but the municipal authorities remain reluctant to engage with them as meaningful partners in the development or evaluation of policies on prostitution. So far, their involvement in local policymaking has been a reactive one.

As was the case in the past, contemporary prostitution policies in Brussels are characterized by a lack of empirical knowledge. First-hand experience, such as input from sex workers, is only used when it supports stereotyping views about commercial 
sex. The expertise of social workers and the police is sometimes taken into account by city officials but it is not valued nearly as much as residents' personal experiences. Local prostitution policies have primarily attempted to deal with society's concerns about the sale of sex and they have developed into populist policymaking. However, that increased popularization has produced positive results as well, since it has prompted the involvement of sex workers in debates.

Historically, petition writing has been one way for ordinary people to make their voices heard (Heerma van Voss, 2001), and women involved in prostitution in Brussels have made use of petitions since at least the nineteenth century. Letters in the City Archives of the Brussels police demonstrate that they did not hesitate to address local authorities to defend their choices or complain about difficulties. Contemporary sex workers continue to do so and, inspired by the activism of their peers elsewhere, they are setting up more formal structures to defend their interests. That empowerment is positive but real change will only occur when all of the actors involved agree to develop evidence-driven policies. A continuation of the initiative launched by ministers Huytebroeck and Smet to stimulate discussions between people both in and outside of the prostitution milieu could be a good start.

\section{Conclusion}

The morality framework proposed by Wagenaar and Altink (2012) is quite useful for analyses of past and present policies on prostitution in Brussels. This study has highlighted the powerful role played by stigma, emotions and conventional ideas about female sexuality in the formulation and implementation of laws on commercial sex. A gendered ideology that treats prostitution as offensive, threatening and morally 
wrong has tended to dominate local regulations and public opinion at large.

Discussions about the issue tend to either vilify the women involved in prostitution or treat them as trafficked victims, and while laws are supposed to be neutral, male and trans sex workers are generally ignored in the legal system.

This case study also demonstrated the increased popularization of policy formulation. While some expertise (particularly that of doctors and hygienists) informed the early system of regulation in Brussels, since the end of the nineteenth century numerous actors have felt that they are entitled to become involved in the debate and influence policymaking. In particular, abolitionist activists and residents have managed to put pressure on the local authorities. Throughout the period studied here, police regulations and administrative sanctions have been adopted, adapted and re-adapted with the sole aim of ghettoizing or repressing prostitution.

Recently, the draconian nature of the measures that are pushing sex work underground have become increasingly contested by the Brussels police, as they are concerned that they will not be able to monitor and control new and more hidden forms of prostitution. Social aid organizations, sex workers and scholars have also become more vocal in their criticism of today's prostitution policies. Their levels of involvement, however, are still rather low and they have not been able to break the predominant tradition of morality politics that dates back to the nineteenth century. As argued by Wagenaar and Altink (2012), four conditions need to be met in the development of laws that are less dogmatic: (1) policymakers must be aware of the dominant ideology that is at the core of prostitution policies; (2) a permanent administrative body that specializes in prostitution policy must be established; (3) an international scholarly network that gathers data on the design and implementation of 
new policies should be created; and (4) the various stakeholders (sex workers, clients, residents and proprietors) must be involved in policymaking.

We would like to add a fifth condition to that list: public awareness must be raised as a means of preventing the perpetuation of dangerous generalizations, myths and gendered misconceptions in discussions about prostitution. Increased cooperation between scholars, sex workers and social assistants has the potential to contribute to the accumulation of first-hand testimonies and the creation of systematic analyses that go beyond the idea of helpless (female) prostitutes and wicked (male) clients and intermediaries of prostitution. Scholarly work on the organization of commercial sex and the profiles of the persons involved in it, as well as sex workers' working and living conditions, agency, migratory patterns and motivations, could also help sensitize the public and increase people's awareness about the adverse effects and inefficient nature of morality politics. 


\section{References}

Beel, V. (2016, 8 April). Frankrijk bestraft voortaan de klanten van prostituees.

'Prostitutie stoppen? Dan moeten alle meisjes dood. De Standaard. Retrieved from http://www.standaard.be/cnt/dmf20160407 02225079

Brussels Hoofdstedelijk Gewest. (2015). Prostitutie. Studie uitgevoerd in 2013-2014 in het kader van de Brusselse Interministeriële Conferentie SociaalGezondheid onder het voorzitterschap van de Minister-President van het Brussels Hoofdstedelijk Gewest. In N. Bailly, I. Thiry, J. François, M. De Gendt \& M. Siaens (Eds.), Brussels Observatorium voor Preventie en Veiligheid, Verslag 2015 (pp. 240-285). Brussels: Brussels Hoofdstedelijk Gewest.

BRUZZ. (2014, 10 September). Stad haalt prostitutiebanken weg. Retrieved from http://www.bruzz.be/nl/nieuws/stad-haalt-prostitutiebanken-weg

BRUZZ. (2014, 16 July). Bij de straatprostituees aan IJzer. Retrieved from http://www.bruzz.be/nl/nieuws/bij-de-straatprostituees-aan-ijzer

BRUZZ. (2016, 9 September). Alhambrawijk: Stad koopt huizen in strijd tegen prostitutie. Retrieved from http://www.bruzz.be/nl/actua/alhambrawijk-stadkoopt-huizen-strijd-tegen-prostitutie

BRUZZ. (2016, 22 February). Emir Kir zet harde aanpak prostitutie verder. Retrieved from http://www.bruzz.be/nl/nieuws/emir-kir-zet-harde-aanpakprostitutie-verder 
BRUZZ. (2016, 28 June). Prostituees Alhambrawijk kunnen weer beboet worden. Retrieved from http://www.bruzz.be/nl/actua/prostituees-alhambrawijkkunnen-weer-beboet-worden

BRUZZ. (2016, 30 May). Nieuwe prostitutieregels Sint-Joost: bordelen dicht bij markt. Retrieved from http://www.bruzz.be/nl/actua/nieuwe-prostitutieregels$\underline{\text { sint-joost-bordelen-dicht-bij-markt }}$

Bulletin communal de la Ville de Bruxelles (1857). Brussels: Archives of the City of Brussels.

Cavaillon, J. A. (1939). Reduction of Demand. In League of Nations, A Study of Preventive Measures, Especially those which Affect Minors. (CQS/A.19c). Geneva: League of Nations Archive.

Chaumont, J.-M. (2009). Le mythe de la traite des blanches: Enquête sur la fabrication d'un fléau. Paris: La Découverte.

Chaumont, J.-M. (2011). The White Slave Trade Affair (1880-1881): A Scandal Specific to Brussels? Brussels Studies, 46. Retrieved from http://www.brusselsstudies.be/medias/publications/EN_133_BruS46EN.pdf doi: $10.4000 /$ brussels. 838

Crowhurst, I. (2017). Without the Shadow of a Doubt? Making Sense of Unknowns and Certainties in Prostitution Policy. In M.-L. Skilbrei \& M. Spanger (Eds.), Prostitution Research in Context: Methodology, Representation and Power (pp. 47-63). Oxford: Routledge. 
Dauvillé, K. (2015, 21 March). In de Alhambrawijk: Prostituees, maffiosi én bewoners. BRUZZ. Retrieved from http://www.bruzz.be/nl/nieuws/dealhambrawijk-prostituees-mafiosi-en-bewoners

David, M., \& Loopmans, M. (2017). Belgium. In H. Wagenaar \& S.O. Jahnsen (Eds.), Assessing Prostitution Policies in Europe (pp. 77-91). London: Routledge.

de Schaepdrijver, S. (1986). Regulated Prostitution in Brussels, 1844-1877: A Policy and its Implementations. Historical Social Research / Historische Sozialforschung, 37, 89-108.

DeRedactie.be. (2011, 2 March). Oudste prostituee van Brussel stopt ermee. Retrieved from http://deredactie.be/cm/vrtnieuws/regio/brussel/1.973762

De Standaard. (2016, 16 February). Balustrade houdt prostituees weg. Retrieved from http://www.standaard.be/cnt/dmf20150216_01531918

DH.be. (2017, 21 August). Prostitution: La police fait son grand retour à Bruxelles. Retrieved from http://www.dhnet.be/regions/bruxelles/prostitution-la-policefait-son-grand-retour-a-bruxelles-5999d8f5cd706e263f805040

Edlund, L., \& Korn, E. (2002). A Theory of Prostitution. Journal of Political Economy, 110(1), 181-214. doi: 10.1086/324390

Foucault, M. (1976). Histoire de la sexualité: La volonté de savoir. Paris: Gallimard.

François, A., \& Machiels, C. (2007). Une guerre de chiffres: L'usage des statistiques par les discours abolitionniste et réglementariste sur la prostitution à Bruxelles (1844-1948). Histoire \& Mesure, 22(2), 103-134. 
Gillis, K. (2016, 21 April). Prostituees uitnodigen vanaf het aperitief. BRUZZ. Retrieved from http://www.bruzz.be/nl/debat/prostituees-uitnodigen-vanafhet-aperitief

Harrington, C. (2017). Gender Policy Models and Calls to "Tackle Demand" for Sex Workers. Sexuality Research and Social Policy, 1-10. doi: 10.1007/s13178$017-0286-9$

Heerma van Voss, L. H. (2001). Introduction. In L. Heerma van Voss (Ed.), Petitions in Social History (pp. 1-10). Cambridge: Cambridge University Press.

Howell, P., Beckingham, D. \& Moore, F. (2008). Managed Zones for Sex Workers in Liverpool: Contemporary Proposals, Victorian Parallels. Transactions of the Institute of British Geographers, 33(2), 233-250.

Hubbard, P. (2004). Cleansing the Metropolis: Sex Work and the Politics of Zero Tolerance. Urban Studies, 41(9), 1687-1702. doi: $10.1080 / 0042098042000243101$

Huberty, C., \& Keunings, L. (1987). La prostitution à Bruxelles au dix-neuvième siècle. Les Cahiers de la Fonderie, 2, 3-21.

ICRSE. (2016, 3 August). Belgium: Utsopi Denounces "Whore Hunt" in Brussels. Retrieved from http://www.sexworkeurope.org/news/general-news/belgiumutsopi-denounces-whore-hunt-brussels

Lavaud-Legendre, B. (2017). Quand le législateur se veut pédagogue... Retour sur les objectives de la loi de lutte contre le système prostitutionnel. Revue de sciences criminelles et de droit pénal comparé. Dalloz, 725-740. 
League of Nations. (1936). Enquiry into Measures of Rehabilitation of Adult Prostitutes. (CTFE 679). Geneva: League of Nations Archive.

League of Nations. (1927). Report of the Special Body of Experts, Part I, Geneva.

Levy, J., \& Jakobsson, P. (2014). Sweden's Abolitionist Discourse and Law: Effects on the Dynamics of Swedish Sex Work and on the Lives of Sweden's Sex Workers. Criminology \& Criminal Justice, 14(5), 593-607. doi:

$10.1177 / 1748895814528926$

Loopmans, M. (2013). Prostitutie, glocalisering en lokaal beleid. Orde van de dag, 64, $20-25$.

Loopmans, M., \& Van Den Broeck, P. (2011). Global Pressures, Local Measures: The Re-Regulation of Sex Work in the Antwerp Schipperskwartier. Tijdschrift voor economische en sociale geografie, 102(5), 548-561. doi: 10.1111/j.14679663.2011.00660.x

Majerus, B. (2003). La prostitution à Bruxelles pendant la Grande Guerre: contrôle et pratique. Crime, Histoire \& Sociétés, 7(1), 5-42. doi: 10.4000/chs.603.

Majerus, B. (2017). Prostitution in Brussels. In J.-M. Chaumont, M. Rodríguez García \& P. Servais (Eds.), Trafficking in Women 1924-1926. The Paul Kinsey Reports for the League of Nations, vol. II (pp. 33-37). Geneva: United Nations Publications.

Massin, V. (2014). La Discipline: Jeunes délinquantes enfermées, violence institutionnelle et réaction disciplinaire: une dynamique (Belgique, 19201970). Crime, History and Societies, 18(1), 31-56. doi: 10.4000/chs.1463 
Mathieu, L. (2015). De monstres ordinaires: La construction du problème publique des clients de la prostitution. Champ pénal/Penal field, XII. Retrieved from http://champpenal.revues.org/9093. doi: 10.4000/champpenal.9093

Maus, I. (1929). De Plicht der Eerlijke Lieden tegenover het Vraagstuk der Prostitutie. Brussels: Belgisch Nationaal Verdediginskomiteit tegen den Handel in Vrouwen en Kinderen.

Parent-Duchâtelet, A. (1838). De la prostitution dans la ville de Paris, considérée sous le rapport de l'hygiène publique, de la morale et de l'administration. Paris: J.-B. Baillière.

Peršak, N. \& Vermeulen, G. (2014). Faces and Spaces of Prostitution. In N. Peršak \& G. Vermeulen (Eds.), Reframing Prostitution: From Discourse to Description, From Moralisation to Normalisation? (pp. 13-24). Antwerp: Maklu.

Picard, E., D'Hoffschmidt, N. \& De Le Court, J. (1886). Pandectes belges: Encyclopédie de législation, de doctrine et de jurisprudence belge. Brussels: Larcier.

Rodríguez García, M. (2012). The League of Nations and the Moral Recruitment of Women. International Review of Social History, 57(20), 97-128. doi: $10.1017 / \mathrm{S} 0020859012000442$

Rodríguez García, M. (2016). Defining Commercial Sexualities, Past and Present. In G. Brown \& K. Browne (Eds.), The Routledge Research Companion to Geographies of Sex and Sexualities (pp. 321-329). Oxford: Routledge. 
Rodríguez García, M., van Nederveen Meerkerk, E., \& Heerma van Voss, L. H. (2017). Selling Sex in World Cities, 1600s-2000s: An Introduction. In M. Rodríguez García, L. Heerma van Voss \& E. van Nederveen Meerkerk (Eds.), Selling Sex in the City: A Global History of Prostitution, 1600s-2000s (pp. 121). Leiden: Brill.

van den Hazel, R., Lesger, D., Peters, T., van Oijen, S., Loopmans, M., Gabiam, K., \& Kesteloot, C. (2008). Prostitutie Brussel in Beeld: Bouwstenen voor een Integraal Prostitutiebeleid. Arnhem: Seinpost Adviesbureau BV.

van Nederveen Meerkerk, E. (2017). A Gender Analysis of Global Sex Work. In M. Rodríguez García, L. H. van Voss \& E. van Nederveen Meerkerk (Eds.), Selling Sex in the City: A Global History of Prostitution, 1600s-2000s (pp. 801-832). Leiden: Brill.

Wagenaar, H., \& Altink, S. (2012). Prostitution as Morality Politics or Why it is Exceedingly Difficult To Design and Sustain Effective Prostitution Policy. Sexuality Research and Social Policy, 9(3), 279-292. doi: 10.1007/s13178012-0095-0

Walkowitz, J. R. (1982). Jack the Ripper and the Myth of Male Violence. Feminist Studies, 8(3), 542-574. doi: 10.2307/3177712

Weitzer, R. (2010). The Mythology of Prostitution: Advocacy Research and Public Policy. Sexuality Research and Social Policy, 7(1), 15-29. doi: $10.1007 / \mathrm{s} 13178-010-0002-5$ 
Weitzer, R. (2014). The Social Ecology of Red-Light Districts: A Comparison of Antwerp and Brussels. Urban Affairs Review, 50(5), 702-730. doi:

$10.1177 / 1078087413504081$ 